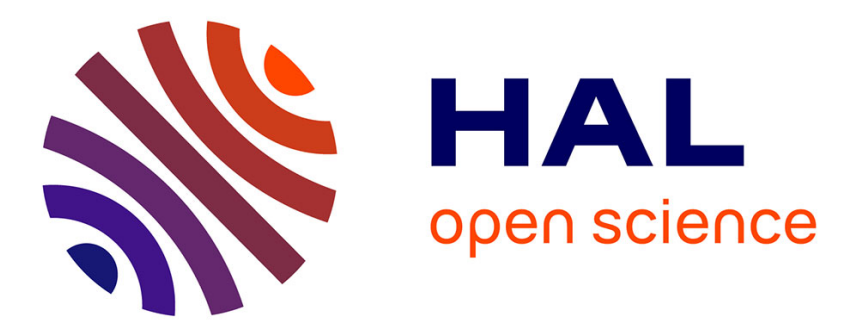

\title{
A magnetic fabric study of the Aigoual-Saint Guiral-Liron granite pluton (French Massif Central) and relationships with its associated dikes.
}

Jean-Yves Talbot, Yan Chen, Michel Faure

\section{- To cite this version:}

Jean-Yves Talbot, Yan Chen, Michel Faure. A magnetic fabric study of the Aigoual-Saint GuiralLiron granite pluton (French Massif Central) and relationships with its associated dikes.. Journal of Geophysical Research: Solid Earth, 2005, 110, pp.B12106. 10.1029/2005JB003699 . hal-00023496

\section{HAL Id: hal-00023496 \\ https://hal-insu.archives-ouvertes.fr/hal-00023496}

Submitted on 2 Nov 2010

HAL is a multi-disciplinary open access archive for the deposit and dissemination of scientific research documents, whether they are published or not. The documents may come from teaching and research institutions in France or abroad, or from public or private research centers.
L'archive ouverte pluridisciplinaire HAL, est destinée au dépôt et à la diffusion de documents scientifiques de niveau recherche, publiés ou non, émanant des établissements d'enseignement et de recherche français ou étrangers, des laboratoires publics ou privés. 


\title{
A magnetic fabric study of the Aigoual-Saint Guiral-Liron granite pluton (French Massif Central) and relationships with its associated dikes
}

\author{
J.-Y. Talbot, ${ }^{1}$ Y. Chen, and M. Faure \\ Institut des Sciences de la Terre d'Orléans, UMR 6113, Université d'Orléans, Orléans, France \\ Received 17 February 2005; revised 5 September 2005; accepted 21 September 2005; published 16 December 2005.
}

[1] In the southeastern French Massif Central, the Aigoual-Saint Guiral-Liron pluton consists of porphyritic and microgranitic types. The latter is encountered within dikes forming the northern end of the pluton. Both types show prefull crystallization microstructures indicating weak subsolidus deformations. An anisotropy of magnetic susceptibility (AMS) study has been carried out to determine the granite fabric. Biotite, local hornblende, and small grains of magnetite are the main carriers of AMS in both types. Porphyritic granite and dikes display different AMS patterns related to magma dynamics and regional deformation recorded during crystallization. In the porphyritic type, the AMS lineation is mainly consistent with the regional, NW-SE to E-W trending, extensional event coeval with emplacement and crystallization of the pluton indicating an influence of regional tectonics on the linear fabric development. The dome shaped foliation pattern of the Saint Guiral massif likely corresponds to internal deformation-related processes within the pluton. In the microgranite dike swarm, the NNE-SSW trending lineations with shallow plunges record magmatic flow processes within dikes, i.e., magma injection and filling of dikes from a probable source located southwestward. Regional tectonics played a significant role in the pluton geometry and fabric development. For example, the NE-SW trend of the dikes suggests that extensional fractures took place in the same extensional strain field as elsewhere in the pluton. Different fabric development modes were therefore responsible for the contrasted fabric patterns between the microgranite and the porphyritic granite.

Citation: Talbot, J.-Y., Y. Chen, and M. Faure (2005), A magnetic fabric study of the Aigoual-Saint Guiral-Liron granite pluton (French Massif Central) and relationships with its associated dikes, J. Geophys. Res., 110, B12106, doi:10.1029/2005JB003699.

\section{Introduction}

[2] Relationships between dikes and plutons have been the topic of many studies during the last 10 years since several authors proposed the "dike propagation" model to explain ascent of granitic plutons [Clemens and Mawer, 1992; Rubin, 1995; Petford, 1996]. However, many observed pluton-dike associations do not correspond to "feeder dikes". On the contrary, many dikes develop in the vicinity of a pluton and appear to be fed by a magma coming from the parental pluton [e.g., Baker, 1998]. Structural studies concerning granitic dikes fed by pluton report essentially their geometric relationships and the orientation of the dike population around the plutons [e.g., Marre, 1986], but their internal fabrics are rarely investigated. By contrast, the internal fabric of granite plutons has been extensively studied for the last 20 years by anisotropy of magnetic susceptibility (AMS) method [e.g., Bouchez, 1997; Benn et al., 1998, 2001, and references therein]. Magnetic fabrics of dikes are also well developed [e.g.,

\footnotetext{
${ }^{1}$ Now at Centre for Geochemical Evolution and Metallogeny of Continent, Department of Earth and Planetary Sciences, Macquarie University, New South Wales, Sydney, Australia.
}

Copyright 2005 by the American Geophysical Union. 0148-0227/05/2005JB003699\$09.00
Callot et al., 2001; Herrero-Bervera et al., 2001; Aubourg et al., 2002], but most of these studies deal with dikes of mafic or rhyolitic composition rather than granitic one except in the study of Hrouda et al. [2002] which concerns syenogranite. Studying internal fabrics of plutons and associated dikes should allow us to understand granitic magma transport and to compare the fabrics in plutons and dikes in order to characterize their relationships and to determine the role of internal dynamics-related deformation and/or regional tectonics on the fabric development in both magmatic bodies.

[3] We have chosen to study the Variscan Aigoual-Saint Guiral-Liron complex, in the southeastern French Massif Central, where a microgranite dike swarm develops at the northern border of a porphyritic granitic pluton. Field observations as well as AMS measurements associated with a microstructural study have been carried out on both lithological types. An emplacement model for the pluton and related dikes in relation with the regional tectonic setting is proposed.

\section{Geological Setting}

2.1. Regional Framework

[4] The French Massif Central belongs to the Paleozoic Variscan Belt of western Europe. It consists of a stack of 


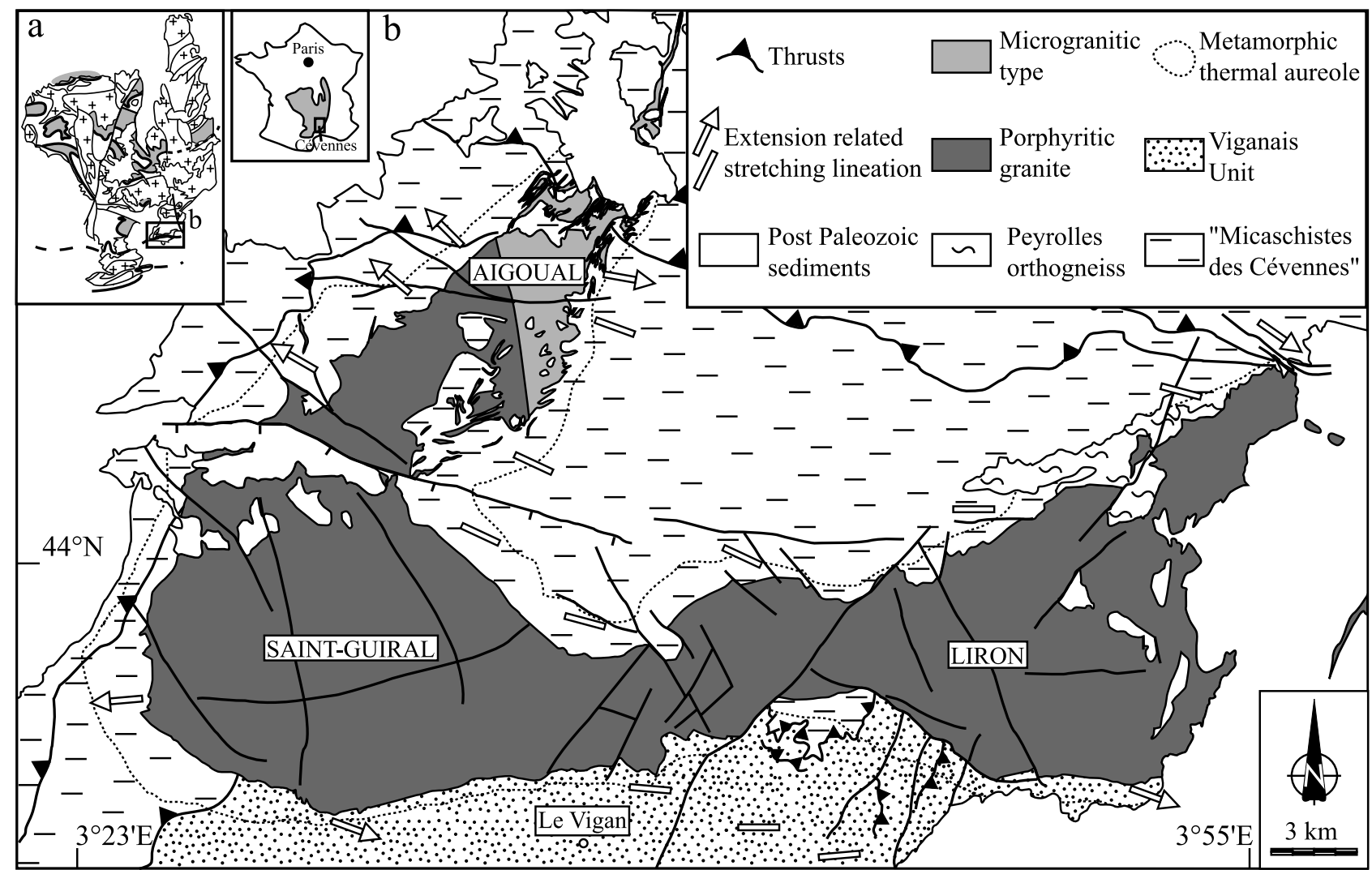

Figure 1. (a) Location map of the study area in the French Massif Central. (b) Structural map of the Aigoual-Saint Guiral-Liron pluton and surrounding areas. White bars and arrows are stretching lineations related to the regional extensional event. Arrows indicate the sense of movement of the upper part.

ductile and metamorphic nappes emplaced from Late Devonian to Middle Carboniferous times [e.g., Ledru et al., 1989]. Crustal thickening is responsible for the voluminous partial melting that gave rise to migmatites and Al-rich granitoids in the Middle to Late Carboniferous. From structural and AMS studies of several of these plutons at different locations within the French Massif Central, it has been demonstrated that they were emplaced during a synorogenic to late orogenic extensional episode characterized by a conspicuous NW-SE directed maximum stretching direction [Faure, 1995; Talbot et al., 2004].

[5] The southeastern part of the French Massif Central, or Cévennes area, is mainly represented by two lithological units tectonically superposed (Figure 1). The lower one, the Viganais Unit, consists of a Cambrian to Ordovician sedimentary sequence of sandstones and carbonates which experienced a slight metamorphism under lower greenschist facies during the Carboniferous [Rakib, 1996]. This unit, which is deformed by south verging recumbent folds and thrusts, is tectonically overthrusted by a micaschist and quartzite metamorphic unit called the "Micaschistes des Cévennes" Unit. This domain underwent a prograde upper greenschist to lower amphibolite facies metamorphism coeval with south directed nappe stacking. A flat-lying foliation (S1) with N-S to NE-SW trending stretching lineation indicates a top-to-the south motion which developed during the thrusting [e.g., Mattauer and Etchecopar, 1977]. The synmetamorphic shearing was dated at 330-
$340 \mathrm{Ma}$ by ${ }^{40} \mathrm{Ar} /{ }^{39} \mathrm{Ar}$ method on biotite and muscovite [Caron, 1994]. A second tectonic phase, characterized by E$\mathrm{W}$ to NW-SE trending stretching lineation and shear bands cutting S1, developed around 315-305 Ma synchronously with the emplacement of several granite plutons, such as the Mont Lozère-Borne pluton in the northern Cévennes (U-Pb monazite ages of $305 \pm 5 \mathrm{Ma}$ and $315 \pm 4 \mathrm{Ma} ;{ }^{40} \mathrm{Ar} /{ }^{39} \mathrm{Ar}$ biotite ages of $310 \pm 3 \mathrm{Ma}$ and $311 \pm 3 \mathrm{Ma}$ [Monié et al., 2000]) and the Aigoual-Saint Guiral-Liron pluton in the southern Cévennes (U-Pb zircon ages of 300-310 Ma; ${ }^{40} \mathrm{Ar} /{ }^{39} \mathrm{Ar}$ biotite ages of $307 \pm 3 \mathrm{Ma}, 308 \pm 3 \mathrm{Ma}$, and $311 \pm 3 \mathrm{Ma}$ [Monié et al., 2000]). All these post-S1 structures are linked to the late Variscan orogenic extension of this area [Faure, 1995; Faure et al., 2001].

\subsection{The Aigoual-Saint Guiral-Liron Pluton}

[6] The Aigoual-Saint Guiral-Liron (ASGL) pluton crops out across the contact zone located between the "Micaschistes des Cévennes" and Viganais units and crosscuts the older thrust contacts (Figure 1). This L-shaped pluton is subdivided into three main massifs, namely, the Aigoual, Saint Guiral and Liron massifs to the north, west and east, respectively (Figure 1). The Saint Guiral massif, which forms the main part of the pluton, is connected eastward through a 3 - to 5 - $\mathrm{km}$-wide neck with the Liron massif whose eastern contact with its country rocks is hidden by Mesozoic sediments. This neck is cut by several NW-SE and NE-SW trending secondary faults that do not 

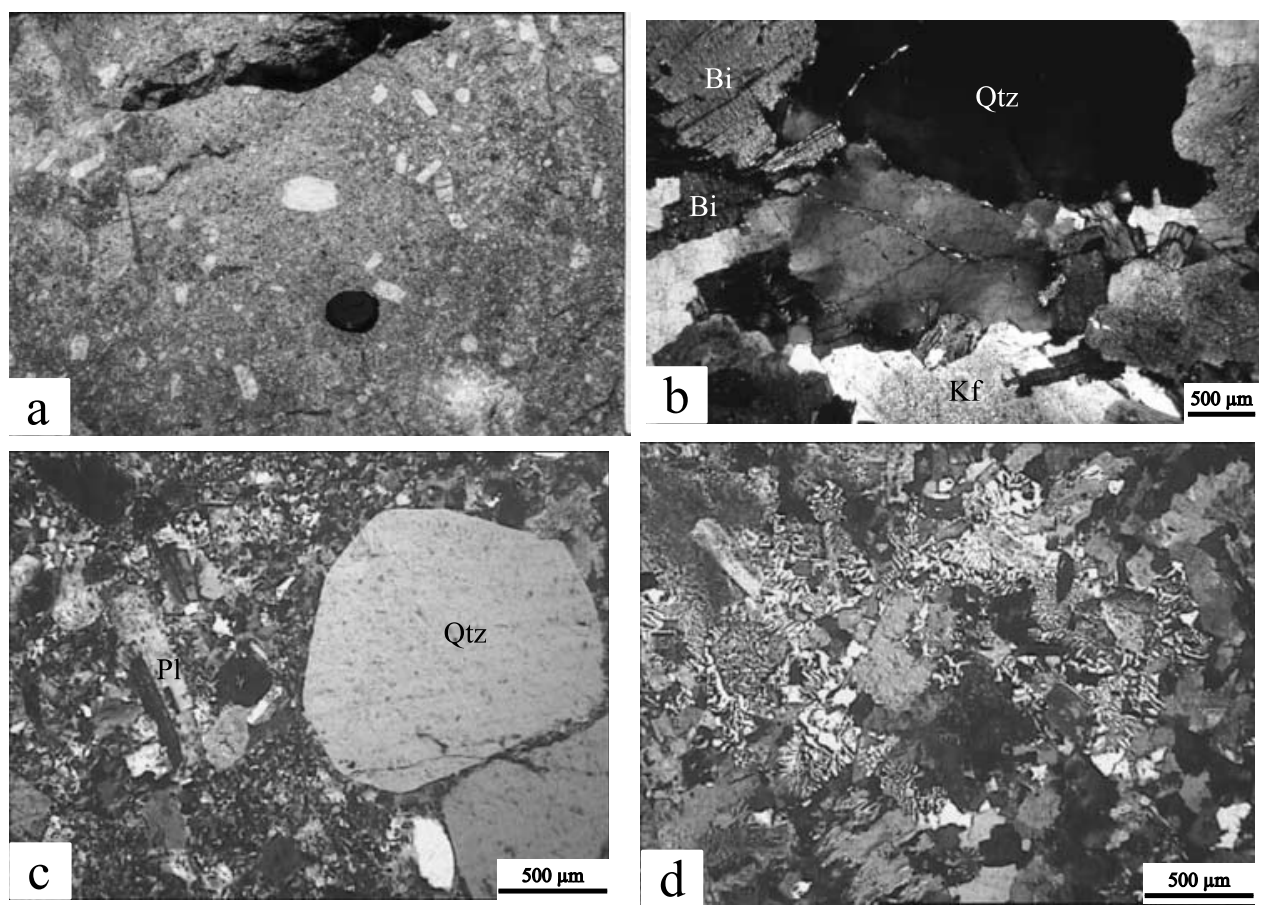

Figure 2. (a) Outcrop of microgranite showing the grey matrix and random fabric of the K-feldspar megacrysts, with some rounded crystals. (b) Typical microstructure of the porphyritic granite showing magmatic microstructures, with few solid-state deformation overprints, minor incipient dynamic recrystallization of quartz and weak kinking of biotite (AG58). (c) Typical microstructure of the microgranite with rounded quartz grains, feldspar and biotite phenocrysts surrounded by a fine-grained quartz-feldspar matrix with rare and small $(50-80 \mu \mathrm{m})$ biotite grains (AG128). (d) Granophyric texture in a microgranite dike (AG139). Qtz, quartz; Kf, K-feldspar; Pl, plagioclase; Bi, biotite.

modify its primary shape, as shown by the continuity of the thermal aureole. The Aigoual granite crops out to the north of Saint Guiral massif. Although separated from each other by a thin cover of Mesozoic sedimentary rocks, these two massifs are in clear petrological and structural continuity. The northern termination of the Aigoual massif consists of a NE-SW to NNE-SSW trending microgranite dike swarm. Available radiometric datings confirm an emplacement age of the ASGL pluton around 305-310 Ma [Monié et al., 2000], coeval with the late Variscan extensional event in this area. These datings also suggest that all the massifs and the granite types of the complex are synchronous. A contact metamorphic aureole, developed around the ASGL complex, is a few hundred meters up to one kilometer in width. Thermobarometric data on hornfelses in this aureole indicate that the pluton was emplaced at 100-200 MPa [Najoui et al., 2000].

\section{Granite Petrography and Microstructures}

\subsection{Two Main Granitic Types}

[7] The ASGL pluton consists of two cogenetic types, porphyritic monzogranite and microgranite [Sabourdy, 1975]. The porphyritic monzogranite type, typical of the Carboniferous plutons of the southeastern French Massif Central, forms the major part of the Saint Guiral and Liron massifs and three quarters of the Aigoual massif. It is composed of millimeter- to centimeter-sized crystals of quartz, plagioclase (oligoclase, andesine), K-feldspar, and biotite surrounding up to 10 -cm-long K-feldspar mega- crysts. Rare hornblendes $(0-2 \%)$ occur either as isolated crystals or associated with biotite in millimeter-sized aggregates where minute epidote and chlorite crystals are also observed.

[8] In the northern and northeastern parts of the Aigoual massif, no strongly localized contact between the porphyritic and the microgranitic types can be observed. Rather, the transition from porphyritic to microgranitic types is progressive. The microgranitic type consists of millimeterto centimeter-sized phenocrysts of rounded quartz, plagioclase, K-feldspar, biotite, and rare hornblendes surrounded by a fine-grained matrix essentially composed of quartz, feldspar, and rare biotite. It is found in meter- to decameterwide dikes within the host micaschists. K-feldspar megacrysts are also observed in this type but are less abundant than in the porphyritic one (Figure $2 \mathrm{a}$ ). They are sometimes absent near the dike margins. At the mesoscopic scale, very few deformations are observed. Locally, particularly along the pluton margins, the K-feldspar megacrysts may show a preferred orientation.

\subsection{Microstructures of the Two Types}

[9] Microstructures were examined in about $50 \%$ of the sampling sites drilled for the AMS study. In the porphyritic granite, most samples display prefull crystallization microstructures indicating deformation in the presence of melt. Quartz grains are slightly deformed by intracrystalline plasticity, with undulose extinction and rare dynamic recrystallization (Figure 2b). Biotite presents no evidence of deformation except in rare cases where crystals are seen to 
be bent or kinked. Feldspars are generally not deformed although exceptionally some of them can display undulose extinction. The porphyritic granite is therefore characterized by magmatic microstructures with only local evidence of a weak high-temperature solid-state deformation [Bouchez et al., 1992; Paterson et al., 1998; Vernon, 2000].

[10] The microgranite dikes have microstructures also consistent with little deformation prior to complete crystallization. In most samples, the phenocrysts of rounded quartz, feldspars and biotite do not show any significant undulose extinction, recrystallization or fracturing. Kinking of a few grains of biotite which could be formed during the crystallization of the microgranite is the only evidence of solid-state deformation. The fine-grained matrix consists of undeformed, 50 to $100 \mu \mathrm{m}$-sized grains (Figure 2c). A few samples however differ from this "standard" microstructure. They have granophyric texture with numerous symplectic relationships between quartz and K-feldpars (Figure 2d). These granophyric textures, found in the matrix and around $\mathrm{K}$-felspars phenocrysts, attest to a fast crystallization in chemical disequilibrium [Hibbard, 1995]. Another peculiar microgranitic texture is characterized by a very fine grained matrix with quartz and feldspar grains ranging from 5 to $50 \mu \mathrm{m}$ in size and biotite almost lacking. This particular texture, preferentially located near the contacts between microgranite and host micaschists, is ascribed to chilled margins of the "standard" microgranite microstructure.

\section{AMS Study}

\subsection{AMS Sampling}

[11] One hundred and thirty six sites comprising 1030 oriented specimens have been drilled for the AMS study among which 125 sites come from the porphyritic type and 11 sites from microgranite dikes (Figure 3). In the porphyritic granite, the sampling was concentrated in the central part of the pluton and the Liron massif. Because of poor exposure conditions, the Saint Guiral massif and the southern part of the Aigoual massif were less explored. At each site, between 4 and 14 specimens were collected. The microgranitic type was mainly investigated in the northern termination of the Aigoual massif. Cores, spaced from one to several meters, were drilled across the dikes. The number of specimens within a dike varies from 5 to 40 depending on the outcrop dike width. Unfortunately, in most cases, due to poor exposure conditions, the contact between the microgranite and the host micaschists was not visible hence the relative positions of the cores with respect to the dike borders were rarely characterized. Therefore the AMS symmetry tests proposed by several authors to determine the sense of magma flow in dikes [e.g., Herrero-Bervera et al., 2001] could not be carried out.

\subsection{Magnetic Mineralogy}

[12] Representative specimens from the two granitic types were characterized for their magnetic mineralogy using several methods. Microscopic investigations reveal that biotite, and more rarely, hornblendes are the main $\mathrm{Fe}$ bearing phases that can potentially carry the magnetic signal. Isothermal remanent magnetization (IRM) has been measured on two specimens from sites AG13 and AG48 of porphyritic granite using an ASC Scientific IM 30 Impulse
Magnetizer and an AGICO JR5 spinner magnetometer (Figure 4a). IRM acquisition increases rapidly and is almost saturated at about $600 \mathrm{mT}$. The IRM curves suggest the presence of ferromagnetic minerals, probably multidomain magnetite. Hysteresis loops of some specimens were determined using a translation inductometer within an electromagnet providing a field of up to $1 \mathrm{~T}$ (Figures $4 \mathrm{~b}$ and $4 \mathrm{c}$ ) at the Paleomagnetic Laboratory of "Institut de Physique du Globe de Paris" (IPGP, Saint Maur, France). For both types, hysteresis curves show almost perfectly linear and reversible induced magnetic moments with increasing and decreasing magnetic fields (Figures $4 \mathrm{~b}$ and $4 \mathrm{c}$ ). This observation emphasizes the dominance of the paramagnetic minerals. After removing the paramagnetic contribution defined from the linear slope above $400 \mathrm{mT}$, the remaining signal is poor and noisy (Figures $4 \mathrm{~b}$ and $4 \mathrm{c}$ ). For the porphyritic granite sample however, a hysteresis loop can be recognized and, although disturbed, indicate the presence of ferromagnetic phases (Figure 4b). Although small in content, these ferromagnetic phases contribute to the AMS signal. As described by Borradaile and Henry [1997], small amounts of fine grained magnetite can strongly affect the magnetic fabric. We therefore demonstrate that paramagnetic minerals, i.e., biotite and accessory hornblendes, and traces of ferromagnetic phases are the main contributors to the AMS.

\subsection{AMS Results}

\subsubsection{Magnetic Susceptibility, Anisotropy Degree and Shape Parameter}

[13] Anisotropy of magnetic susceptibility was measured with an AGICO KLY 3S apparatus. Magnetic susceptibility values, $\mathrm{Km}$, of the two rock types are quite similar (Figure 5 and Table $\mathrm{S} 1$ in the auxiliary material ${ }^{\mathrm{l}}$ ). For the porphyritic granite, $\mathrm{Km}$ shows a unimodal distribution, mainly from 60 to $215 \mu \mathrm{SI}$, except for two sites, with a mean value of $147 \pm$ $31 \mu$ SI. Because of the small number of sampling sites in the microgranite relative to the porphyritic granite (11 against 125), we present the data for the 172 microgranite specimens. Those display a unimodal distribution of susceptibility magnitude ranging from 74 to $373 \mu$ SI with a mean at $168 \pm 38 \mu$ SI, i.e., slightly higher than in the porphyritic granite. The $150-200 \mu$ SI susceptibilities for both types are typical of granite where paramagnetic phases are the main contributors to AMS [Bouchez, 1997].

[14] Two parameters, $\mathrm{T}$ and $\mathrm{P}^{\prime}$, describe the shape of the AMS ellipsoid [Jelinek, 1978, 1981]. Since the susceptibilities of our samples are low, the diamagnetic contribution to the rock matrix, mainly due to quartz and feldspar, must be taken into account. This contribution is considered as isotropic and with a constant value of $\mathrm{Kd}=-13.6 \mu \mathrm{SI}$ [Rochette, 1987]. T and $\mathrm{P}^{\prime}$ parameters have been corrected for diamagnetism (Table S1). The shape parameter is given by $\mathrm{T}=[2 \times \ln ((\mathrm{K} 2-\mathrm{Kd}) /(\mathrm{K} 3-\mathrm{Kd})) /(\ln ((\mathrm{K} 1-\mathrm{Kd}) /(\mathrm{K} 2-$ $\mathrm{Kd})$ )] -1 where $\mathrm{K} 1 \geq \mathrm{K} 2 \geq \mathrm{K} 3$ are the AMS principal axes [Hrouda, 1982]. It qualifies the shape of the ellipsoid, prolate $(\mathrm{T}<0)$ or oblate $(\mathrm{T}>0)$. The anisotropy degree, $\mathrm{P}^{\prime}=$ $\exp \sqrt{ }\left[2 \times \Sigma(\ln (\mathrm{Ki}-\mathrm{Kd})-\ln (\mathrm{Km}-\mathrm{Kd}))^{2}\right]$ where $\mathrm{i}=$ $1,2,3$ and $\mathrm{Km}=(\mathrm{K} 1+\mathrm{K} 2+\mathrm{K} 3) / 3$, is an indicator of

${ }^{1}$ Auxiliary material is available at $\mathrm{ftp} / / \mathrm{ftp}$.agu.org/apend/jb/ 2005JB003699. 


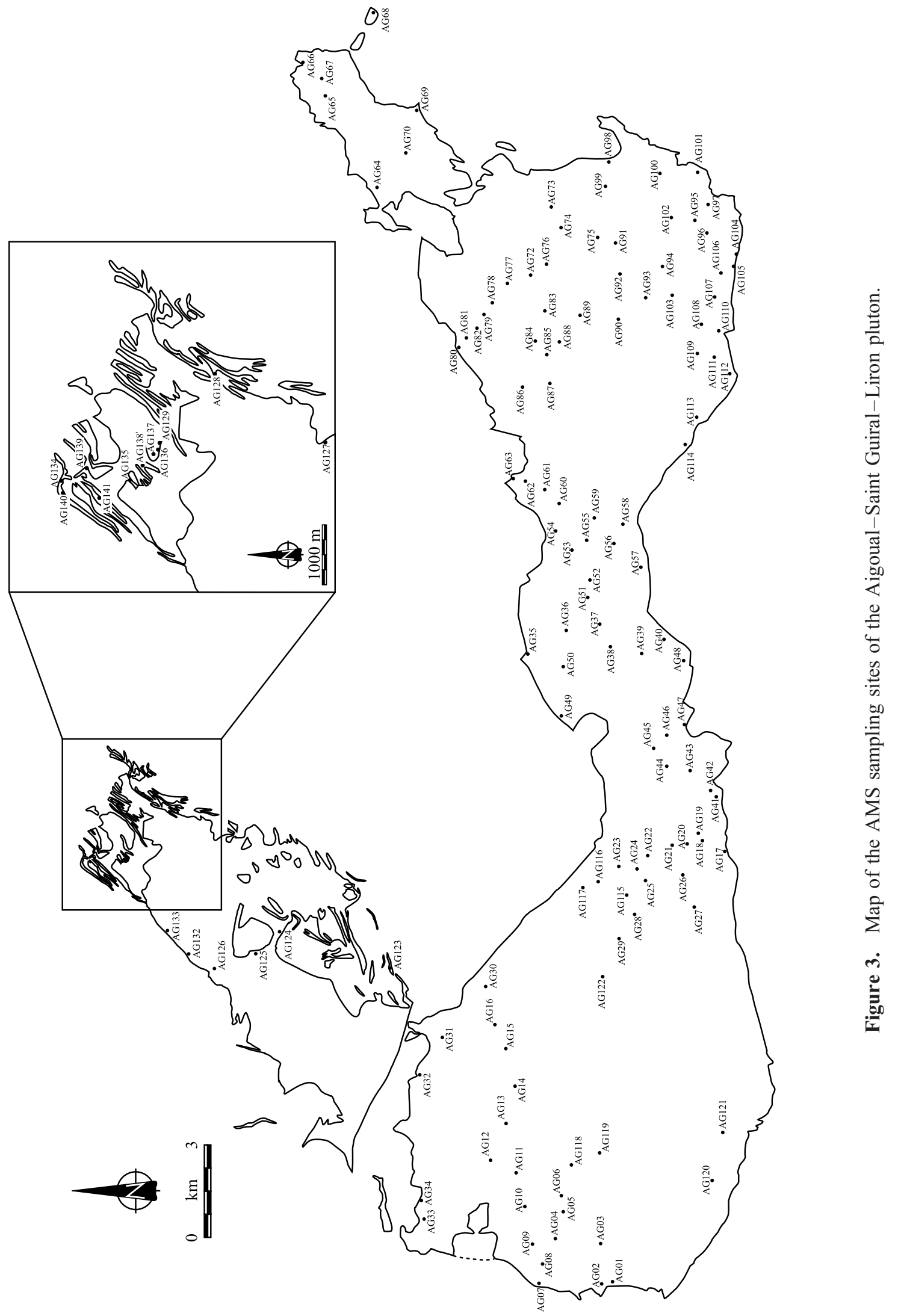



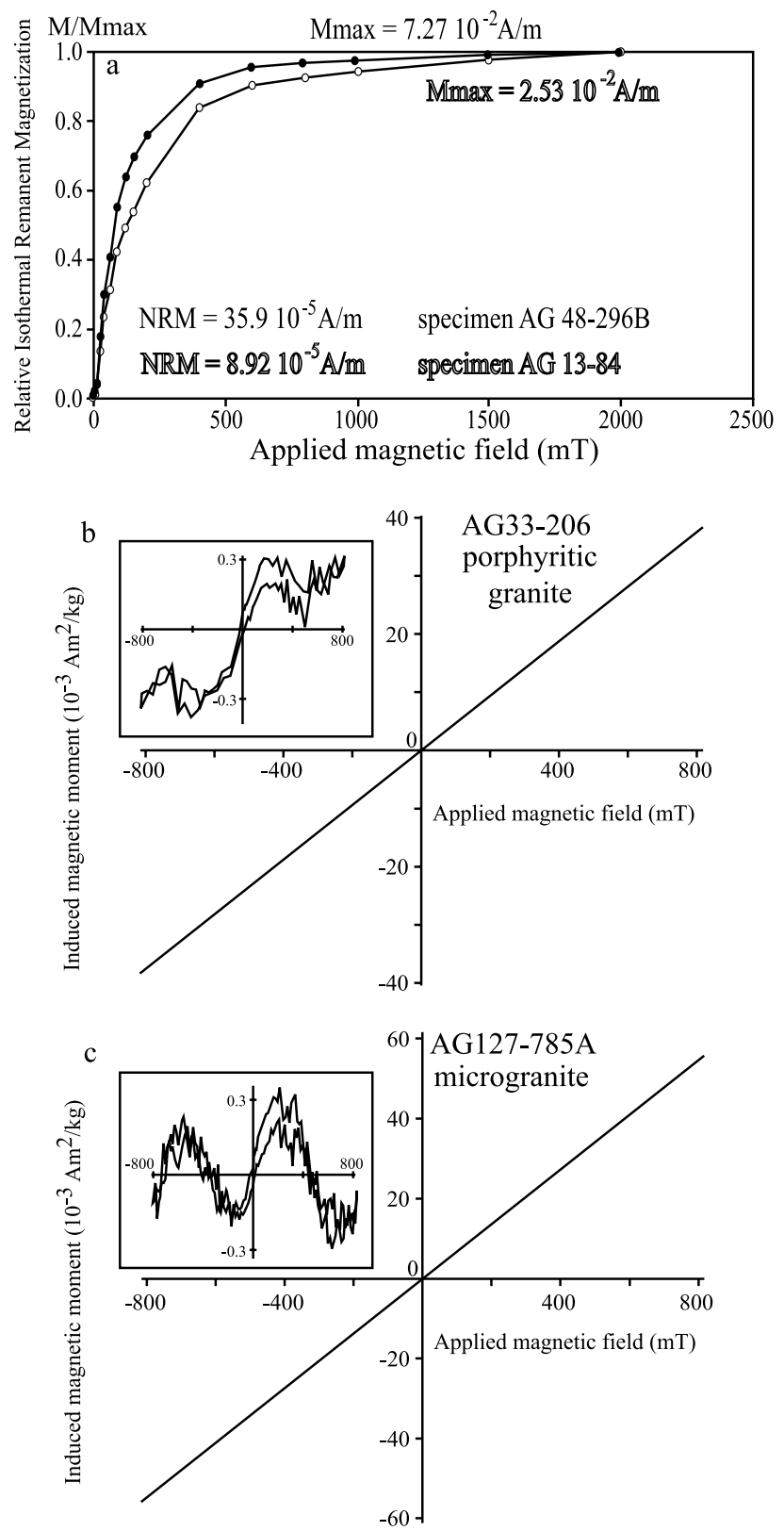

Figure 4. (a) Acquisition of isothermal remanent magnetization, showing a magnetic saturation with weak IRM intensity. Hysteresis curves of (b) porphyritic granite and (c) microgranite showing linear and superposing induced magnetic moments with respect to increasing and decreasing applied magnetic fields. Insets show the signal after removing the paramagnetic contribution.

the strength of the AMS ellipsoid. The plot of $\mathrm{P}^{\prime}$ vs. T [Jelinek, 1978, 1981; Hrouda, 1982] shows that T values are scattered for the porphyritic granite (Figure 6), while $\mathrm{P}^{\prime}$ values are weak since more than $90 \%$ of them are less than 1.03, and only two sites have $\mathrm{P}^{\prime}$ higher than 1.04. $\mathrm{P}^{\prime}$ is even weaker in the microgranite with values not exceeding 1.02 and almost half of them weaker than 1.01. These values are weaker than those generally obtained in "paramagnetic" granites where commonly $\mathrm{P}^{\prime}=1.03-1.05$ [Bouchez, 1997]. The shape of the AMS ellipsoid of the microgranite is generally oblate shape

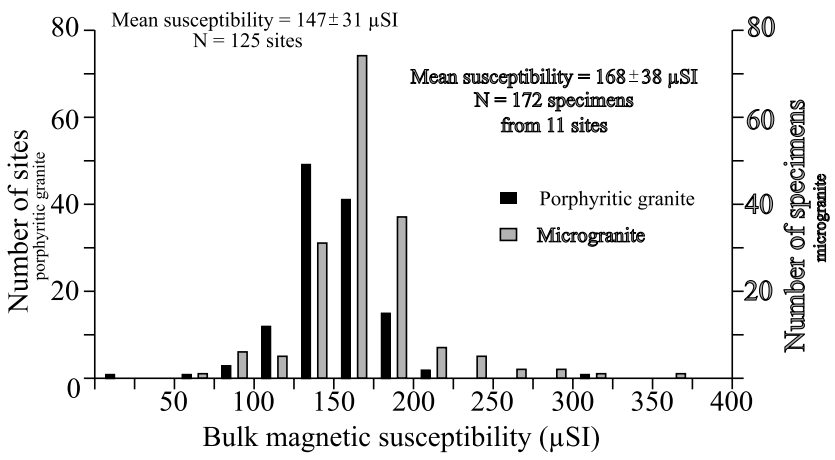

Figure 5. Histograms of magnetic susceptibility for each site of porphyritic granite (125 sites) and all specimens of microgranite (175 specimens from 11 sites).

$(\mathrm{T}>0)$. Although no obvious correlation between $\mathrm{P}^{\prime}$ and $\mathrm{T}$ can be observed for both rock types, sites with high $\mathrm{P}^{\prime}$ values $\left(\mathrm{P}^{\prime}>\right.$ 1.03 ) tend to have oblate ellipsoids. However, as reported by Borradaile and Henry [1997], small amounts of fine-grained magnetite in inclusions within Fe-bearing silicates (micas, amphiboles) can strongly affect $\mathrm{P}^{\prime}$ and $\mathrm{T}$. Hence variations of those scalar parameters could be influenced by small differences in magnetic mineralogy (i.e., magnetite content) rather than be due to variations of strain magnitudes.

\subsubsection{Influence of Magnetite Content on AMS Directional Data}

[15] Because small amounts of magnetite can strongly affect the AMS data, it is important to determine whether the subfabric of the ferromagnetic fraction is parallel to the subfabric of the paramagnetic phases. Following Borradaile and Gauthier [2001], we suppose that specimens showing the highest bulk susceptibilities have the highest magnetite content, hence their bulk fabrics might be the most affected by the subfabric of magnetite. In our data set, a threshold of $\mathrm{Km}=175 \mu$ SI seems appropriate to distinguish between specimens having "few magnetite" grains from those containing magnetite grains. For the porphyritic granite, a difference of about $20-25^{\circ}$ is observed for the principal magnetic susceptibility axes between low bulk susceptibil-

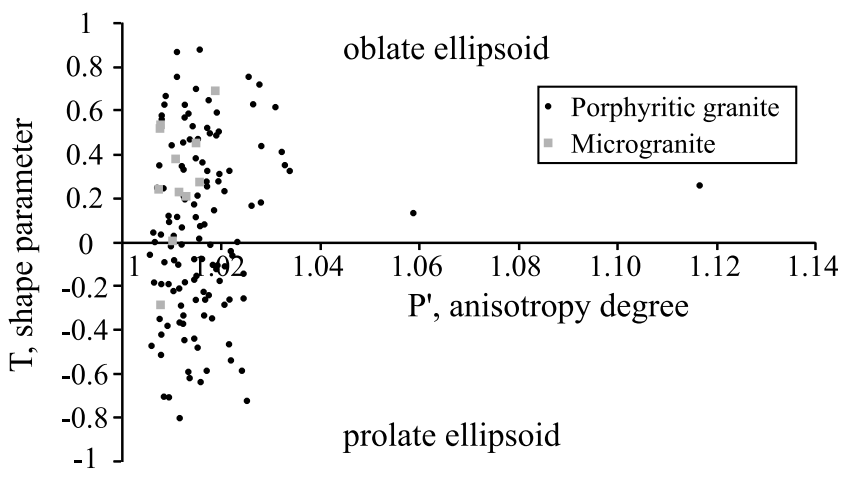

Figure 6. Anisotropy degree $\left(\mathrm{P}^{\prime}\right)$ against shape parameter (T). $\mathrm{P}^{\prime}$ and $\mathrm{T}$ are corrected from the diamagnetic contribution, $\mathrm{Kd}=-13.6 \mu \mathrm{SI}$. Black dots and grey squares represent site averages of porphyritic granite and microgranite, respectively. 


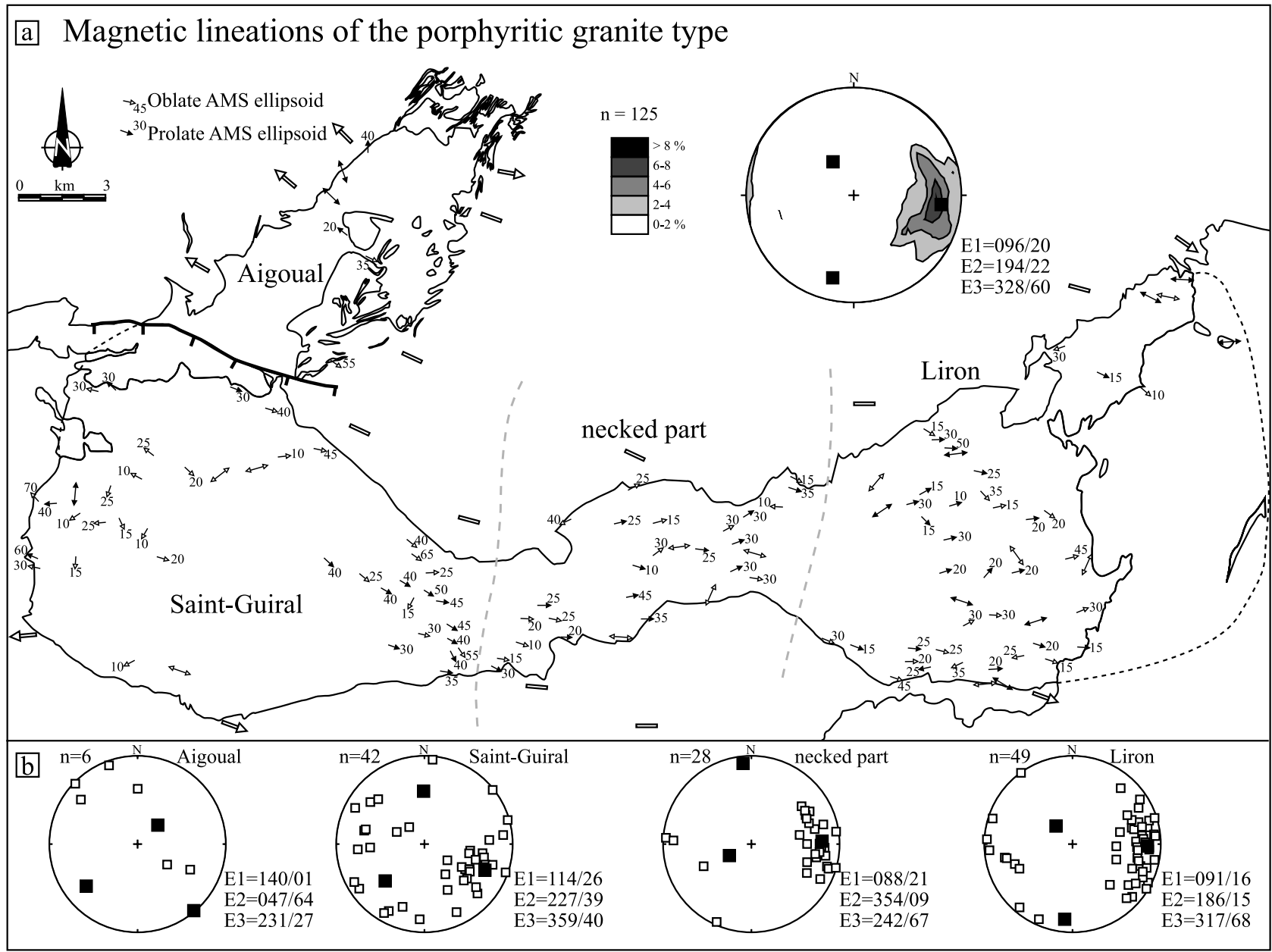

Figure 7. (a) Map of magnetic lineations of the 125 sampling sites of the porphyritic granite type of the Aigoual-Saint Guiral-Liron pluton and corresponding contour lower hemisphere projection. In the host rocks, white bars are the stretching lineation and arrows give the sense of shear of the upper part. (b) Equal-area, lower-hemisphere projections of magnetic lineations (open squares) for the four parts of the porphyritic granite type. Black squares are the three eigenvectors $(\mathrm{E} 1>\mathrm{E} 2>\mathrm{E} 3)$ of the distributions.

ity specimens and high bulk susceptibility specimens $(\mathrm{K} 1=$ $097^{\circ} / 21^{\circ}$ and $072^{\circ} / 23^{\circ} ; \mathrm{K} 3=289^{\circ} / 68^{\circ}$ and $304^{\circ} / 54^{\circ}$, respectively). For the microgranite, a smaller difference of about $10-15^{\circ}$ is observed between low bulk susceptibility specimens and high bulk susceptibility specimens $(\mathrm{K} 1=$ $020^{\circ} / 22^{\circ}$ and $012^{\circ} / 25^{\circ} ; \mathrm{K} 3=140^{\circ} / 51^{\circ}$ and $128^{\circ} / 43^{\circ}$, respectively). These data suggest that the magnetite subfabric might be slightly different from the paramagnetic subfabric. An examination of results of each site suggests, however, that the magnetite subfabric does not greatly influence the results of AMS directional data at the pluton scale.

4.3.3. AMS Fabric Patterns of the Porphyritic Granite

[16] As attested by the equal-area, lower-hemisphere projections (Figures $7 \mathrm{~b}$ and $8 \mathrm{~b}$ ), moderate to shallow eastward plunging magnetic lineations dominate in the porphyritic granite, although some variations exists depending on location in the pluton. The poles to magnetic foliation (K3) are more scattered, although a general eastward dip is predominant (Figure 8a). In the Liron massif and in the necked part, magnetic lineations (K1) trend $\mathrm{N} 70^{\circ} \mathrm{E}$ to $\mathrm{N} 120^{\circ} \mathrm{E}$ with moderate eastward plunges (Figure $7 \mathrm{a}$ ), except in the northeastern termination where very shallow plunges are observed. These widespread NW-SE to E-W trending magnetic lineations are consistent with the general trend of stretching lineations found in the host rocks (Figure 7a). The foliations are more scattered with some arcuate patterns, mainly in the necked part and the central part of the Liron massif, but a dominant eastward dip is observed (Figure 8a). Very close to the pluton margins, foliations often trend $\mathrm{E}-\mathrm{W}$, that is parallel to the contact, and dip steeply. The poles to the foliations seem to have girdle-like distributions which might suggest the occurrence of folds in these parts (Figure 8b). In the Aigoual massif, the lineation pattern is also consistent with the general trend of stretching lineations found in the host rocks, with NW-SE trending lineations except in the two northernmost sites where N-S to NNW-SSE trends are recorded (Figures $7 \mathrm{a}$ and $7 \mathrm{~b}$ ). Foliations strike $\mathrm{N} 30^{\circ} \mathrm{W}$ to $\mathrm{N} 20^{\circ} \mathrm{E}$ and dip eastward or westward (Figure 8a). In the Saint Guiral massif, the pattern is different and defines a dome-shaped structure. Near the borders, magnetic lineations plunge outward with moderate to high angles. Foliations, with also an outward dip, are commonly parallel to these borders (Figures $7 \mathrm{a}$ and $8 \mathrm{a}$ ). 


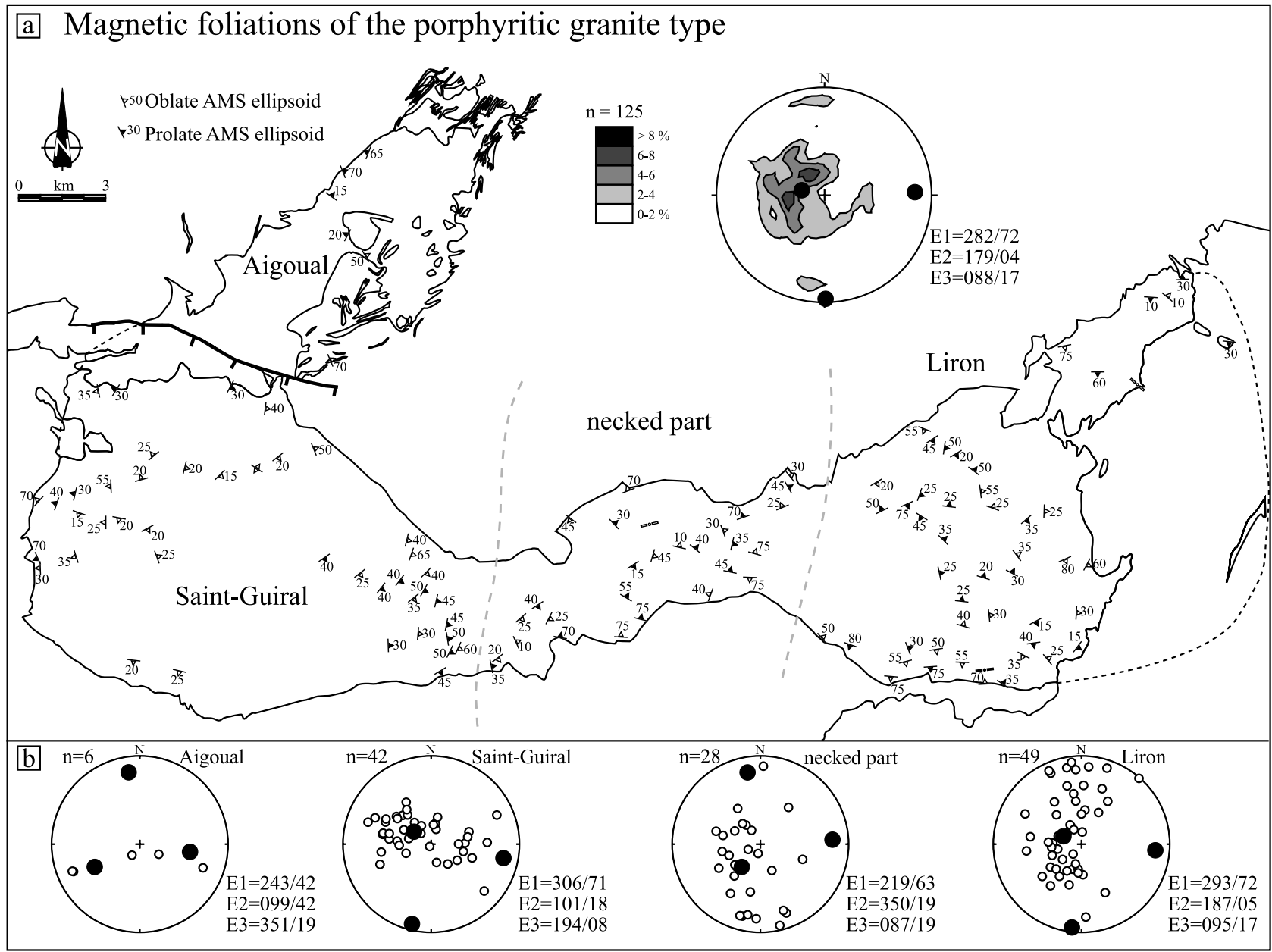

Figure 8. (a) Map of magnetic foliations of the 125 sampling sites of the porphyritic granite type of the Aigoual-Saint Guiral-Liron pluton and corresponding contour lower hemisphere projection of poles to foliation. (b) Equal-area, lower-hemisphere projections of poles to magnetic foliations (open dots) for the four parts of the porphyritic granite type. Black dots are the three eigenvectors $(E 1>E 2>E 3)$ of the distributions.

Inside the massif, the foliations have shallow dips and so, various strikes. The trend of shallow-dipping lineations is also very scattered. To the east, magnetic fabrics show SE to eastward lineation plunges and foliations dips. Except to the eastern part of the Saint Guiral massif, the dome-shaped pattern is not parallel with the NW-SE directed regional extension.

4.3.4. Magnetic Fabric Within the Microgranite Dikes

[17] Although more scattered than in the porphyritic body (Figure 9a), the orientations in the microgranite dikes tend to cluster into a mean lineation trending $\mathrm{N} 10^{\circ} \mathrm{E}$ to $\mathrm{N} 50^{\circ} \mathrm{E}$ with shallow plunges, and foliations strike, on average, NESW and dip to the northwest (Figure 9b). Some sites (AG 138, AG 140 and AG 141) may display inverse fabrics although the interpretation is difficult since the margins of the dikes are not always observed. Foliations show various strikes which could be related to their general shallow dip (Figure 9b). To the east part of the dike swarm, foliations generally strike about N-S with moderate to steep eastward and westward dips. To the west part, the foliation strikes $\mathrm{N} 40^{\circ}-70^{\circ} \mathrm{E}$ with moderate to steep northwestward dips.
Lineations trend $\mathrm{N}-\mathrm{S}$ with shallow plunge, to the east part, whereas, to the west, the $\mathrm{N} 10^{\circ}-45^{\circ} \mathrm{E}$ trending lineations display shallow to moderate plunges. However, the data for individual sites are highly scattered, and sometimes the principal axes, K1 and K3, can be blended (Figure 9a). This feature is associated with very low $\mathrm{P}^{\prime}$ values. Nevertheless, despite the scattering, the mean magnetic lineation trend is commonly parallel to the general strike direction of the dikes, i.e., NNE-SSW to NE-SW.

[18] Figure 10 presents a detailed AMS across-dike study from site AG134. Km is constant throughout the dike. $\mathrm{P}^{\prime}$ is higher near the NW border than in the inner part of the dike. The shape parameter, $\mathrm{T}$, is always oblate but decreases from dike margins to core. The fabric data display strong variations with steeper lineation plunges in the central part. Foliation is vertical in the center and dip northwestward at both of the dike margins. These variations could be related to the weak values of $\mathrm{P}^{\prime}$. They might also suggest multiple intrusive phases, or other local effects such as wall rock displacements [Correa-Gomes et al., 2001]. Although, the others dikes also show variations of AMS parameters, it is 


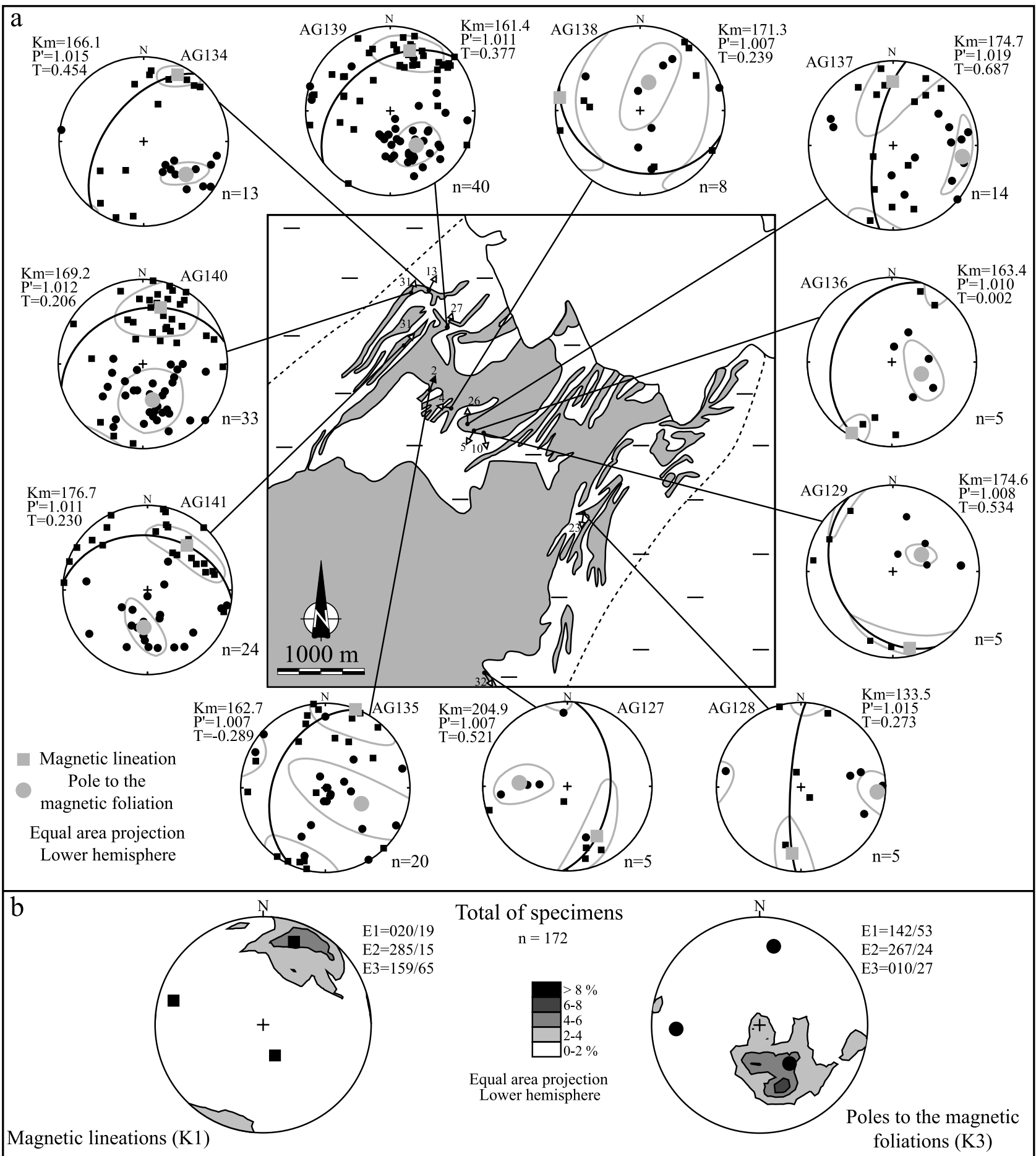

Figure 9. (a) Equal-area, lower-hemisphere projections of AMS results for each sampling site of the microgranitic type of the northern part of the Aigoual granite. Squares and circles are K1 (magnetic lineation) and K3 (pole to the magnetic foliation), respectively. Small black symbols and larger grey ones represent individual specimen and average orientation directions, respectively. The 95\% confidence ellipses are drawn around average orientation directions. Trace of the magnetic foliation, (K1, K2) plane, is also plotted. $\mathrm{Km}, \mathrm{P}^{\prime}$, $\mathrm{T}$, and $\mathrm{n}$ stand for mean magnetic susceptibility, anisotropy degree, shape parameter, and number of specimens, respectively. In the geological map, the symbols are the same as those of Figure 1. (b) Equal-area, lower-hemisphere contour projection of the magnetic lineations and the poles to magnetic foliations for all specimens of microgranite. Black squares and dots are the three eigenvectors $(\mathrm{E} 1>\mathrm{E} 2>\mathrm{E} 3)$ of the distributions. 

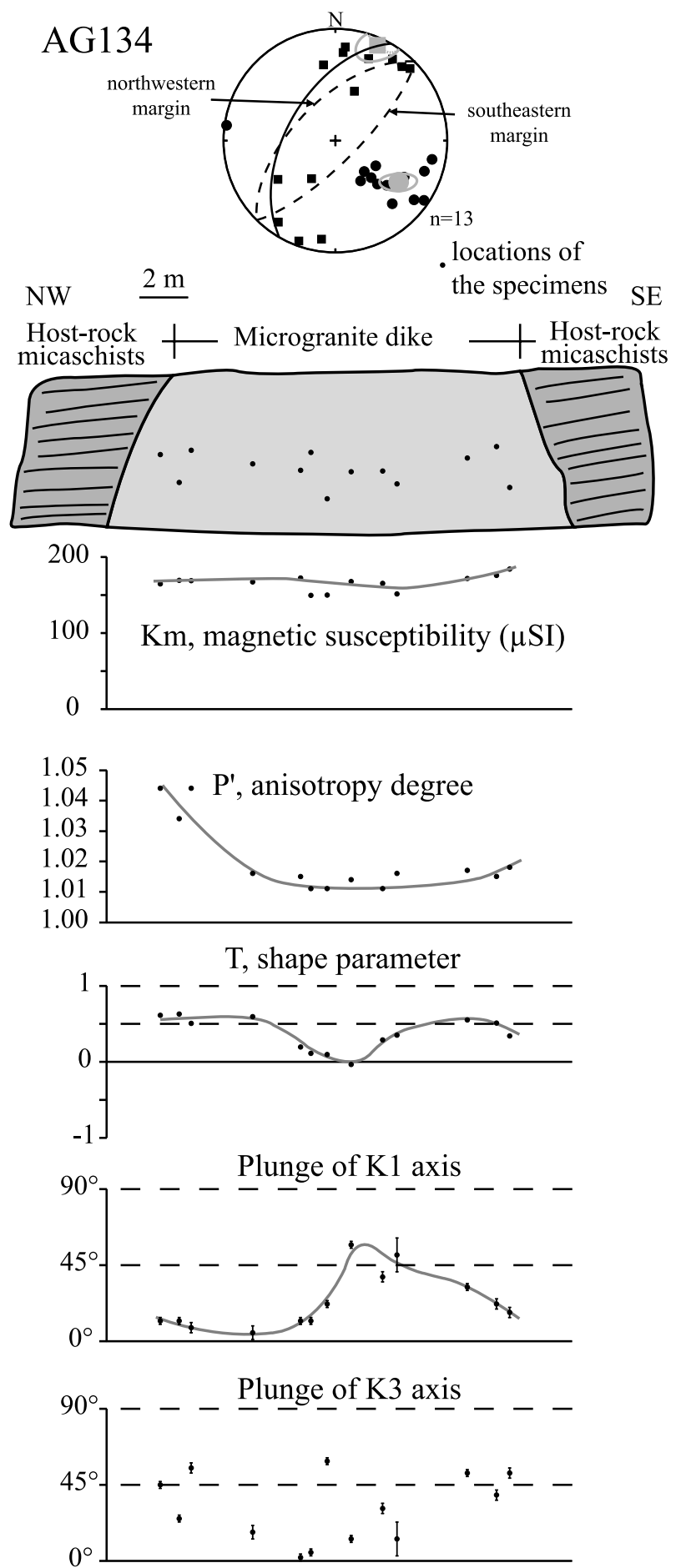

Figure 10. Cross section through a microgranite dike (site AG134) showing variations of different AMS parameters across the dike. Grey lines represent the mean variations of the different parameters. Error bars correspond to the $95 \%$ confidence angle. In the equal-area, lower-hemisphere projection, dashed great circles are the two margins of the dike and black great circle is the trace of the magnetic foliation, (K1, K2) plane. very difficult to interpret these variations since the margins of these dikes are rarely observed.

\section{Discussion}

\subsection{Relationships Between Magnetic Fabrics and Regional Structures}

[19] Fabric patterns, in granite plutons, can either result from internal magma chamber processes such as convection, magma surges, dike injection, or be related to the regional deformation, or a combination of these two processes [Paterson et al., 1998]. Comparing the synemplacement strain markers in the host rock with internal magnetic and deformation fabrics allows us to determine the degree of geometric and/or structural coupling between the two sets of structural data [Benn et al., 1998, 2001]. If synemplacement structures in host rock are in geometric continuity with those inside the pluton, these latter features may reflect the effect of regional deformation. Conversely, if foliations and lineations are different between host rocks and pluton, structures in the pluton will preferentially be considered to be the result of internal processes in the pluton.

[20] Since the ASGL pluton crosscuts thrust contacts in the metamorphic country rocks, structures in the pluton must have developed after the nappe stacking and internal compressional deformation of the Cévennes units probably around 305-310 Ma [Monié et al., 2000] when the Cévennes underwent a postthickening extension [Faure, 1995]. NW-SE to E-W trending stretching fabrics are well documented around the ASGL pluton [Faure, 1995]. In the contact aureole, a $\mathrm{N} 80^{\circ} \mathrm{E}$ to $\mathrm{N} 150^{\circ} \mathrm{E}$ trending crenulation and mineral lineation is well developed. Boudinage of cherty limestones in the Viganais unit to the south of the pluton is also consistent with E-W stretching. Contact metamorphic minerals, such as biotite or graphitic andalusite, coeval with granite emplacement and crystallization, trend NW-SE to E-W and they are boudinaged or bent. Quartz pressure shadows at the extremities of biotite porphyroblasts in the metamorphic aureole also show stretching in this NW-SE extensional direction. The lineation is generally subhorizontal except near the western border of the pluton where it plunges steeply toward the NW. Finally, to the north of the Aigoual granite, the mean trend of the microgranite dike swarm, i.e., NNE-SSW to NE-SW, is consistent with E-W to NW-SE stretching. The microgranite dikes are interpreted as extensional fractures opened by a NW-SE stretching and filled by granitic magma.

[21] In the porphyritic granite, NW-SE to E-W trending magnetic lineations are well developed throughout the pluton except in the Saint Guiral massif where dome-shaped structures are observed (Figure 11). This E-W pattern is similar to the synemplacement structures described in the host rock. This contrasts with the magnetic lineations in microgranite dikes which are nearly perpendicular to the regional NW-SE to E-W stretching direction observed both in the porphyritic granite and its host rock.

\subsection{Significance of the AMS Data}

[22] The consistency between magnetic lineations in the porphyritic granite and regional extensional structures strongly suggests that the fabric of this granite type was influenced by the regional deformation. The Liron granite 


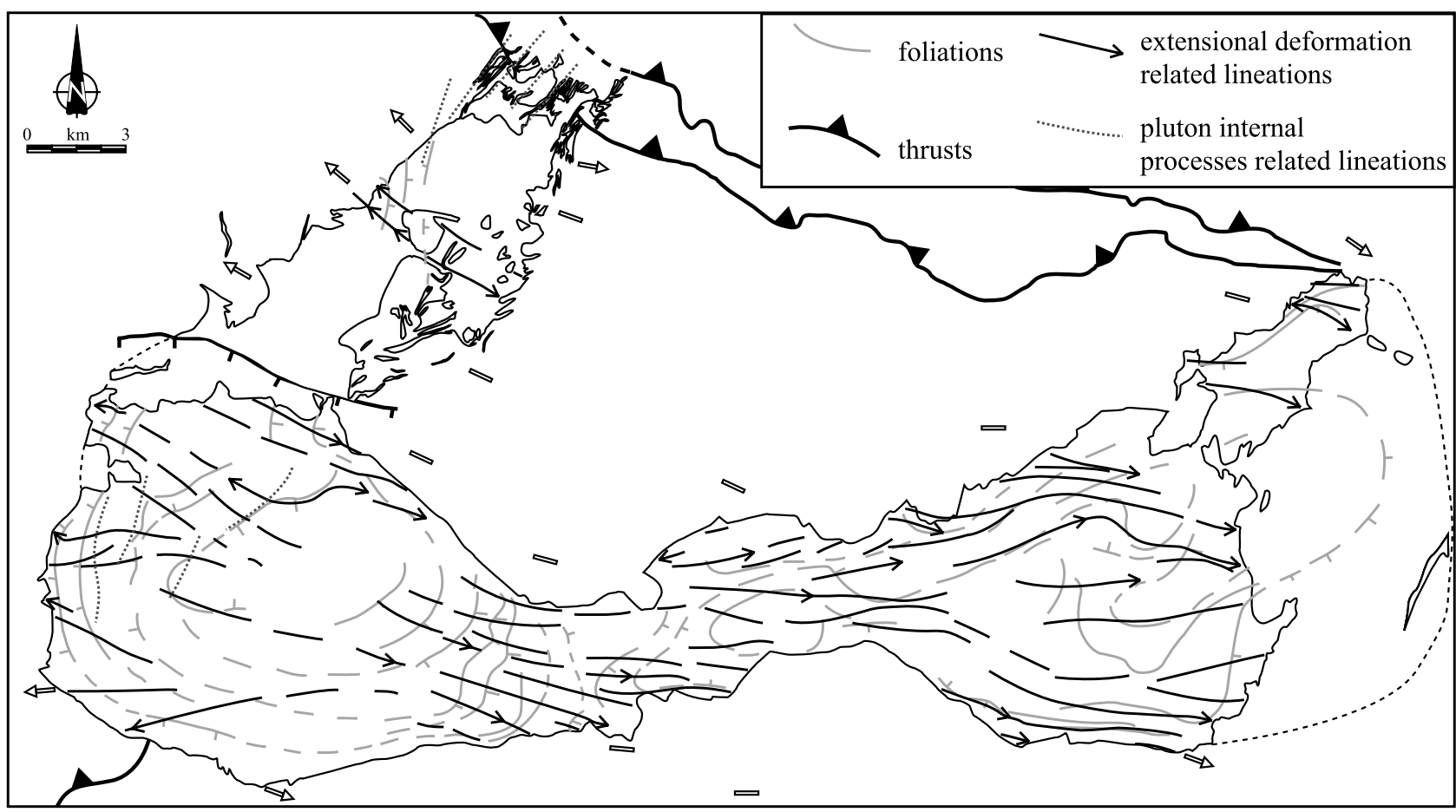

Figure 11. Structural sketch of the trajectories of magnetic lineation and foliation for both porphyritic and microgranitic types. The distinction made between the different kinds of lineations, internal processes or extensional deformation related, is based on the comparison between those lineations and the stretching lineations of the host rock reported by Faure [1995]. Dotted lines are lineation trends related to internal processes (see text for further explanations). Arrows on thick black lines indicate the plunge direction. White bars and arrows in the host rock are the mineral and stretching lineation and sense of shear of the upper part, respectively.

presents the simplest pattern with roughly E-W magnetic lineations, close to the regional E-W trajectories of stretching deformation (Figure 11). In the necked part, the magnetic lineation trend exhibits a scattered pattern that could either be related to magma flow or reflect a wrench component of strain during fabric acquisition or would result from rigid rotations of granite blocks along the numerous NW-SE and NE-SW trending late faults cutting this area. The general shallow eastward dip of the pluton structures in the necked part and the Liron massif could be due to an eastward tilting of these areas during or after their emplacement. The dome-shaped pattern of the magnetic structures in the Saint Guiral granite is not parallel with the regional extensional deformation. However, strain induced by regional stresses during crystallization can lead to an "onion skin" pattern of structures as described by Paterson et al. [1998]. This dome-shaped pattern could be also related to a core-complex-like deformation associated to the regional extensional deformation. However, this fabric pattern of the Saint Guiral massif may be also interpreted by using the gravity map of the area (Figure 12) [Bureau de Recherches Géologiques et Minières, 1998] showing that the most negative anomaly lies in the Saint Guiral massif and to the south of the Aigoual and decrease eastward. Although this anomaly is rather broad, the two-dimensional gravity models of L. Améglio (unpublished data, 1998) propose a thickness of $5 \mathrm{~km}$ for the Saint Guiral massif whereas the eastern and northern parts of the pluton are thinner, down to $2-3 \mathrm{~km}$. Negative anomalies and deep- ening of pluton floors are commonly interpreted as reflecting feeder zones [Guillet et al., 1985; Vigneresse, 1990; Améglio et al., 1997]. We contend therefore that the domal foliation shape could be a consequence of pluton inflation above a feeder area and so, it would reflect internal

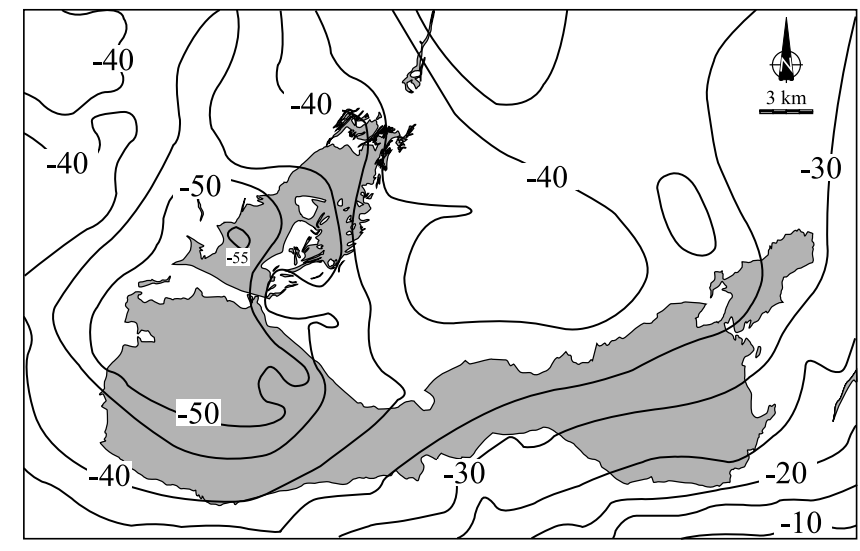

Figure 12. Map of the complete Bouguer gravity anomaly (in $\mathrm{mGal}$ ) in Aigoual-Saint Guiral-Liron pluton area drawn from the map of the Bouguer anomaly of the whole France [Bureau de Recherches Géologiques et Minières, 1998]. The maximum negative anomaly, located in the Saint Guiral and the southern part of the Aigoual granite, may be considered as the thickest part of the whole pluton. 


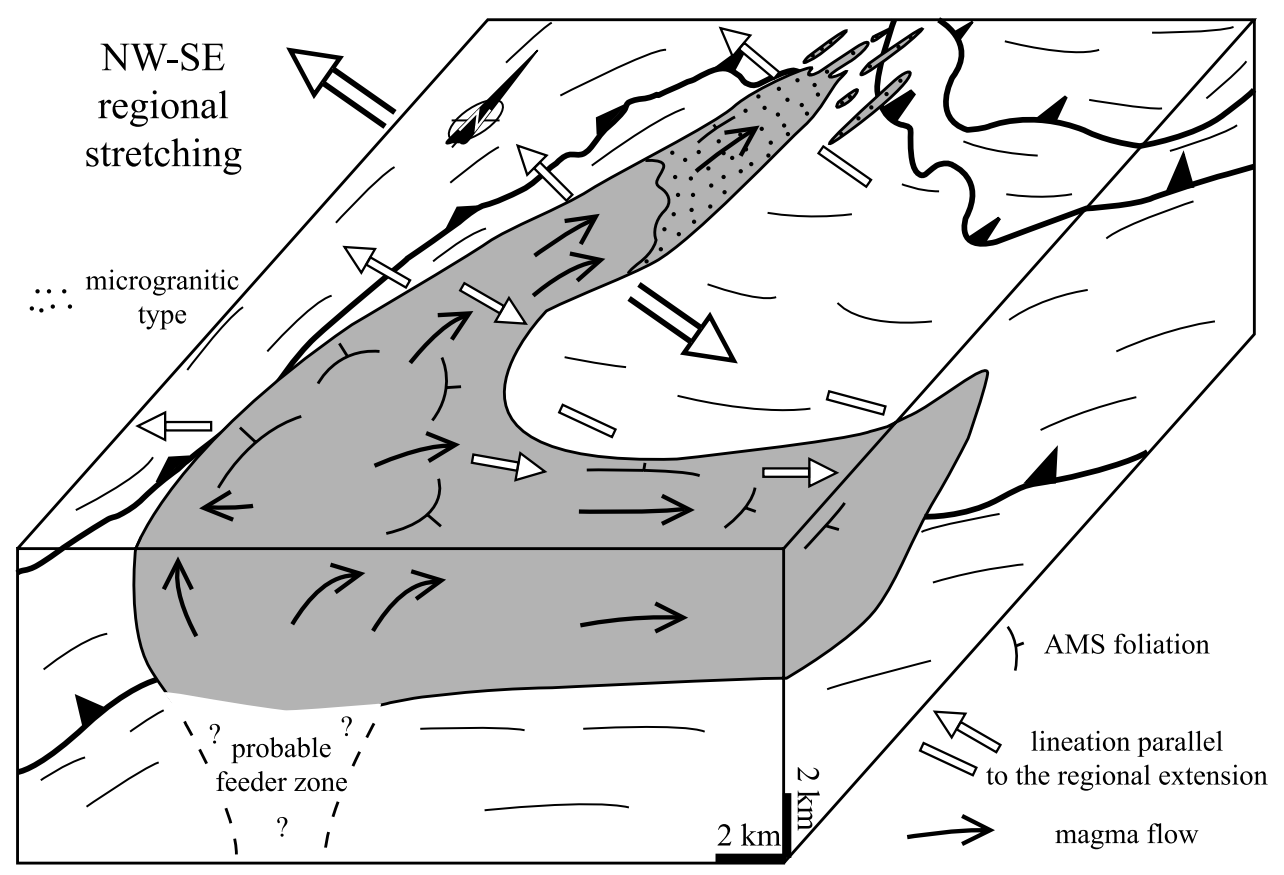

Figure 13. Three-dimensional schematic representation of the Aigoual-Saint Guiral-Liron pluton showing the main trajectories of AMS foliation, magma flow, and lineation parallel to the regional extension in the host rock and in the granite. Dotted pattern is the microgranitic type.

magmatic processes within the pluton. We note that the eastward main flow of the magma from this feeder zone would be parallel to the regional extensional deformation (Figure 13). Finally, in the Aigoual massif, the magnetic lineations in the porphyritic granite are mostly parallel to the stretching lineations measured in the contact aureole.

[23] The influence of the regional deformation on fabric formation in the porphyritic granite can result from different processes. It has been proposed that granite plutons can record some increments of the regional strain [Benn et al., 1998, 2001]. However, the regional deformation could also create a mechanical anisotropy of the country rocks. This mechanical anisotropy would have been responsible for the overall E-W elongation of the major part of the pluton, and as a consequence, the flow of the magma would be expected to be constrained by the shape of the space being filled. This process would have resulted in NW-SE to E-W trending magnetic lineations in the major part of the pluton.

[24] By contrast, the microgranite dikes do not show any fabric relationship with the regional stretching direction since the magnetic lineations parallel the mean NNE-SSW dike trends. The magnetic fabrics in the dikes are therefore interpreted as reflecting the internal magmatic flow within the dikes. Unfortunately, in the Aigoual massif, the transition zone between regional deformation-related fabrics to the south and internal processes-induced fabrics to the north is not visible since this zone is poorly exposed. However, the two northernmost sampling sites in the porphyritic granite, which are the nearest to the dike area, yield N-S to NNW-SSE trending lineations close to that observed in the microgranite. Accepting that the feeder zone of the pluton lies below the Saint Guiral massif and the southern part of the Aigoual pluton, the NE-SW lineation trends in the dikes comply with a southwestward source for the feeding direction of these dikes (Figure 13). Although some steeply plunging lineations are observed in these dikes, the magma flow was likely mainly subhorizontal as indicated by the common shallow plunge of lineations. Indeed, Poland et al. [2004] measured in silicic dikes around a stratovolcano, a general subhorizontal magma flow, with locally steep flow vectors due to irregularities in dike geometry. This suggests that even in a dike where magma flow is mainly subhorizontal, significant local variations of flow occur. This could also explain the fact that, in the microgranite dikes, the results of AMS specimens are commonly scattered.

[25] The difference of fabric pattern, and particularly of magnetic lineation trend, between the main porphyritic body and the microgranite dikes may be due to either a peculiar magnetic mineralogy or to a particular deformation regime. The magnetic mineralogy study has evidenced no difference between porphyritic and microgranitic types, hence the different AMS patterns are not likely due to contrasted mineralogy. In addition, the similar prefull crystallization microstructures observed in both types indicate that fabric was acquired during magma cooling. Concerning the influence of the regional deformation on fabric acquisition, it could be argued that the northern part of the Aigoual granite was not affected by the regional strain. However, this assumption is not consistent with the ductile deformation that developed in the thermal aureole around the dike swarm which is similar to that observed around the rest of the pluton. Moreover, the N-S to NE-SW trend of the dikes shows that their opening is related to the regional NW-SE extension, confirming that the regional strain field is the same in each part of the pluton. We therefore contend that in 
the microgranite dikes, the AMS fabric pattern has recorded magma flow during their filling. Conversely, in the porphyritic type, the AMS pattern has been mainly influenced by the late orogenic extensional regional deformation.

\section{Conclusions}

[26] The porphyritic and microgranitic types of the Aigoual-Saint Guiral-Liron pluton present several common and different features. The contrasted fabric patterns measured in the two types do not result from different magnetic mineralogies since biotite, local hornblende, and traces of magnetite carry in both types the magnetic signal. Prefull crystallization microstructures observed in both types of rock indicate a very minor subsolidus imprint. Indeed, the different AMS patterns reflect different development modes of the fabrics. In the major part of the porphyritic granite, the magnetic fabric, and more particularly the magnetic lineation, was generally influenced by deformation related to the late orogenic extensional tectonics, either by recording some increments of the regional stresses or by being associated to a magma flow parallel to the regional stretching direction. Conversely, in the microgranite dikes, flow related to the magma internal dynamics is the main driving force of the AMS. The fabric would be related to the filling of the dikes from a southwestward source. The dynamics of flow is likely quite complex as shown by the variations of AMS parameters across one dike. Further investigations are necessary to better constrain the structural relationships between granites and associated dikes and particularly in the transition zone between both magmatic bodies.

[27] Acknowledgments. Scott Paterson is thanked for fruitful discussions during a field trip on magma emplacement mode and fabric formation. Maxime Le Goff allowed us to carry out the measurements of hysteresis curves at the Paleomagnetic Laboratory of IPGP. Keith Benn, Paul Kelso, Jean-Luc Bouchez, Alexander Cruden, and Associate Editors Graham Borradaile and Ernie Rutter are thanked for their thorough and constructive reviews of the different versions of the manuscript.

\section{References}

Aubourg, C., G. Giordano, M. Mattei, and F. Speranza (2002), Magma flow in sub aqueous rhyolitic dikes inferred from magnetic fabric analysis (Ponza Island, W. Italy), Phys. Chem. Earth, 27, 1263-1272.

Améglio, L., J. L. Vigneresse, and J. L. Bouchez (1997), Granite pluton geometry and emplacement mode inferred from combined fabric and gravity data, in Granite: From Segregation of Melt to Emplacement Fabrics, edited by J. L. Bouchez, D. H. W. Hutton, and W. E. Stephens, pp. 199-214, Springer, New York.

Baker, D. R. (1998), The escape of pegmatite dikes from granitic plutons: Constraints from new models of viscosity and dike propagation, Can Mineral., 36, 255-263.

Benn, K., N. M. Ham, G. S. Pignotta, and W. Bleeker (1998), Emplacement and deformation of granites during transpression-Magnetic fabrics of the Archean Sparow pluton, Slave Province, Canada, J. Struct. Geol., 20, $1247-1259$

Benn, K., S. R. Paterson, S. P. Lund, G. S. Pignotta, and S. Kruse (2001), Magmatic fabrics in batholiths as markers of regional strains and plate kinematics: Example of the Cretaceous Mt. Stuart batholith, Phys. Chem. Earth, 26, 343-354.

Borradaile, G. J., and D. Gauthier (2001), AMS-detection of inverse fabrics without AARM, in ophiolite dikes, Geophys. Res. Lett., 28, 3517-3520.

Borradaile, G. J., and B. Henry (1997), Tectonic applications of magnetic susceptibility and its anisotropy, Earth Sci. Rev., 42, 49-93.

Bouchez, J. L. (1997), Granite is never isotropic: An introduction to AMS studies of granitic rocks, in Granite: From Segregation of Melt to Emplacement Fabrics, edited by J. L. Bouchez, D. H. W. Hutton, and W. E. Stephens, pp. 95-112, Springer, New York.

Bouchez, J. L., C. Delas, G. Gleizes, A. Nédélec, and M. Cuney (1992), Submagmatic microfractures in granites, Geology, 20, 35-38.
Bureau de Recherches Géologiques et Minières (1998), Carte de l'anomalie de Bouguer de la France métropolitaine et du plateau continental, Orléans, France.

Callot, J. P., L. Geoffroy, C. Aubourg, J. P. Pozzi, and D. Mege (2001), Magma flow directions of shallow dikes from the East Greenland volcanic margin inferred from magnetic fabric studies, Tectonophysics, 335, $313-329$.

Caron, C. (1994), Les minéralisations Pb-Zn associées au Paléozoïque inférieur d'Europe méridionale. Traçage isotopique $\mathrm{Pb}-\mathrm{Pb}$ des gîtes de l'Iglesiente (SW Sardaigne) et des Cévennes et évolution de socle encaissant par la géochronologie U-Pb, ${ }^{40} \mathrm{Ar}-{ }^{39} \mathrm{Ar}$ et $\mathrm{K}-\mathrm{Ar}$, Ph.D. thesis, 288 pp., Univ. de Montpellier II, Montpellier, France.

Clemens, J. D., and C. K. Mawer (1992), Granitic magma transport by fracture propagation, Tectonophysics, 204, 339-360.

Correa-Gomes, L. C., C. R. Souza Filho, C. J. F. N. Martins, and E. P. Oliveira (2001), Development of symmetrical and asymmetrical fabrics in sheet-like igneous bodies: The role of magma flow and wall-rock displacements in theoretical and natural cases, J. Struct. Geol., 23, $1415-1428$.

Faure, M. (1995), Late orogenic Carboniferous extensions in the Variscan French Massif Central, Tectonics, 14, 132-153.

Faure, M., X. Charonnat, A. Chauvet, Y. Chen, J. Y. Talbot, G. Martelet, G. Courrioux, P. Monié, and J. P. Milési (2001), Tectonic evolution of the Cévennes para-autochthonous domain of the Hercynian French Massif Central and its bearing on ore deposits formation, Bull. Soc. Geol. Fr., 172, 687-696.

Guillet, P., J. L. Bouchez, and J. L. Vigneresse (1985), Le granite de Plouaret (Bretagne): Mise en évidence structurale et gravimétrique de diapirs emboîtés, Bull. Soc. Geol. Fr., 1, 503-513.

Herrero-Bervera, E., G. P. L. Walker, E. Cañon-Tapia, and M. O. Garcia (2001), Magnetic fabric and inferred flow direction of dikes, conesheets and sill swarms, Isle of Skye, Scotland, J. Volcanol. Geotherm. Res., 106, $195-210$.

Hibbard, M. J. (1995), Petrography to Petrogenesis, 608 pp, Prentice-Hall, Upper Saddle River, Cliffs, N. J.

Hrouda, F. (1982), Magnetic anisotropy of rocks and its application in geology and geophysics, Geophys. Surv., 5, 37-82.

Hrouda, F., M. Chlupáèová, and J. K. Novák (2002), Variations in magnetic anisotropy and opaque mineralogy along a kilometer deep profile within a vertical dike of the syenogranite porphyry at Cínovec (Czech Republic), J. Volcanol. Geotherm. Res., 113, 37-47.

Jelinek, V. (1978), Statistical processing of anisotropy of magnetic susceptibility measured on groups of specimens, Stud. Geophys. Geodet., 22, $50-62$.

Jelinek, V. (1981), Characterization of the magnetic fabric of rocks, Tectonophysics, 79, 563-567.

Ledru, P., J. M. Lardeaux, D. Santallier, A. Autran, J. M. Quénardel, J. P. Floc'h, G. Lerouge, N. Maillet, J. Marchand, and A. Ploquin (1989), Où sont les nappes dans le Massif central français?, Bull. Soc. Geol. Fr., 5, $605-618$.

Marre, J. (1986), The Structural Analysis of Granitic Rocks, 123 pp, Elsevier, New York.

Mattauer, M., and A. Etchecopar (1977), Argumentation en faveur de chevauchements de type himalayen dans la chaîne hercynienne du Massif Central français, Colloq. Int. CNRS, 268, 261-267.

Monié, P., J. P. Respaut, S. Brichaud, V. Bouchot, M. Faure, and J. Y. Roig (2000), ${ }^{40} \mathrm{Ar} /{ }^{39} \mathrm{Ar}$ and U-Pb geochronology applied to Au-W-Sb metallogenesis in the Cévennes and Châtaigneraie districts (Southern Massif Central, France), in Orogenic Gold Deposits in Europe, Doc. B. R. G. M., 297, 77-79.

Najoui, K., A. F. Leyreloup, and P. Monié (2000), Conditions et âges ${ }^{40} \mathrm{Ar}{ }^{39} \mathrm{Ar}$ de mise en place des granitoïdes de la zone externe sud du Massif central français: Exemple des granodiorites de St-Guiral et du Liron (Cévennes, France), Bull. Soc. Geol. Fr., 171, 495-510.

Paterson, S. R., T. K. Fowler Jr., K. L. Schmidt, A. S. Yoshinobu, E. S. Yuan, and R. B. Miller (1998), Interpreting magmatic fabric patterns in plutons, Lithos, 44, 53-82.

Petford, N. (1996), Dykes and diapirs?, Trans. R. Soc. Edinburgh Earth Sci., 87, 105-114.

Poland, M. P., J. H. Fink, and L. Tauxe (2004), Patterns of magma flow in segmented silicic dikes at Summer Coon volcano, Colorado: AMS and thin section analysis, Earth Planet. Sci. Lett., 219, 155-169.

Rakib, A. (1996), Le métamorphisme régional de basse pression des Cévennes occidentales: Une conséquence directe de la mise en place du dôme thermique vellave (Massif Central français), Ph.D. thesis, 207 pp., Univ. de Montpellier II, Montepellier, France.

Rochette, P. (1987), Magnetic susceptibility of the rock matrix related to magnetic fabric studies, J. Struct. Geol., 9, 1015-1020.

Rubin, A. M. (1995), Getting granite dikes out of the source region, J. Geophys. Res., 100, 5911-5929. 
Sabourdy, G. (1975), Apport de la géochimie à la connaissance de la pétrogenèse des granitoïdes des Cévennes méridionales, Massif central français, Ph.D. thesis, 278 pp., Univ. de Clermont-Ferrand, ClermontFerrand, France.

Talbot, J. Y., G. Martelet, G. Courrioux, Y. Chen, and M. Faure (2004), Emplacement in an extensional setting of the Mont Lozère-Borne granitic complex (SE France) inferred from comprehensive AMS, structural and gravity studies, J. Struct. Geol., 26, 11-28.

Vernon, R. H. (2000), Review of microstructural evidence of magmatic and solid-state flow, Electr. Geosci., 5(2).
Vigneresse, J. L. (1990), Use and misuse of geophysical data to determine the shape at depth of granitic intrusions, Geol. J., 25, 249-260.

Y. Chen and M. Faure, Institut des Sciences de la Terre d'Orléans, UMR 6113, Université d'Orléans, BP 6759, F-45067 Orléans Cedex 2, France.

J.-Y. Talbot, GEMOC, Department of Earth and Planetary Sciences, Macquarie University, NSW 2109, Sydney, Australia. (jtalbot@els.mq. edu.au) 